\title{
INFORMATION AS MOBILIZING FACTOR OF SOCIAL ACTIVITY OF PERSONALITY
}

\section{ІНФОРМАЦІЯ ЯК МОБІЛІЗУЮЧИЙ ЧИННИК СОЦІАЛЬНОЇ АКТИВНОСТІ ОСОБИСТОСТІ}

\author{
Mykola Sanakuiev ${ }^{1}$
}

DOI: https://doi.org/10.30525/978-9934-26-001-8-3-5

Abstract. The subject of the study is information as a mobilizing factor in social activity. Taking into account the subject of the research and the corresponding national peculiarities of this complex social phenomenon, structural and functional, historical-comparative, comparative-critical methods of research were used. In particular, the comparative-criticalapproach was used in the analysis of existing concepts and versions of mobilization in the philosophical and historical context. Structural-functional approach was used in the analysis of elements of social capital, as a system of social interaction. The historical-comparative approach was used in the format of the analysis of the genesis of the concept of informative communication, for tracking historically predetermined trends of development and changes in society, depending on the growth of the amount of information. The purpose of this article is to study the mobilization qualities of the phenomenon of information space in the life of modern Ukrainian society. The results of the research reveal the causal links of the functioning of the state information policy of modern Ukraine, as a stimulating factor for the development and mobilization of human capital. On the way to the information society in Ukraine, there are a number of obstacles that need to be taken into account when developing the state information policy. Among them, it should be noted: the lack of digital information resources, low electronic literacy of the population, the lack of public television and radio broadcasting sites, the confrontational tone of socially important topics, the existence of biased journalism and prohibited topics.

\footnotetext{
${ }^{1} \mathrm{PhD}$ (Philosophical), Senior Researcher,

V.I. Vernadsky National Library of Ukraine, Ukraine.

ORCID: https://orcid.org/0000-0001-7725-6117
}

(C) Mykola Sanakuiev 


\section{1. Ветуп}

Україна - молода держава 3 великими перспективами, люди що живуть тут $-\epsilon$ найціннішим ресурсом, який ії створює та формує. Найактивніші соціальні елементи це саме молодь, яка творить їі майбутнє. Для мобілізації та прогресу будь-якого суспільства мають бути створені відповідні сучасні умови, які відповідають сьогоднішнім запитам для розвитку, як на індивідуальному рівні, так і на рівні соціальних систем.

Нестача інформаційних ресурсів на цифровій основі, низька електронна грамотність населення, відсутність громадських площадок теле- i радіомовлення, конфронтаційний тон суспільно вагомої тематики, наявність замовної журналістики і заборонених тем, все це постає на шляху до інформаційного суспільства України в ролі перешкод, які слід враховувати при опрацюванні державної інформаційної політики.

В науковому дискурсі існує недостатня наукова розробка цілої низки теоретичних і методологічних аспектів проблем інформації та інформаійної комунікації, як головних чинників розвитку суспільства.

Метою дослідження виступає аналіз мобілізаційних якостей феномену інформаційного простору в житті сучасного українського суспільства. Результати дослідження виявляють причинно-наслідкові зв'язки функціонування державної інформаційної політики сучасної України, як стимулюючого фактору розвитку і мобілізації людського капіталу.

Досягнення поставленої мети передбачає розв'язання низки взаємопов’язаних дослідницьких завданнь:

- уточнити зміст сучасних підходів, щодо проблем інформації та інформаційної комунікації, які пов'язані з проблемою соціального капіталу;

- визначити інтегруючу властивість інформації у функціонуванні суспільства як системи;

- обгунтувати вплив нових форм комунікації на стан соціальної взаємодії;

- уточнити особливості функціонування інформаційної комунікації на прикладі українського соціуму.

Предметом дослідження $\epsilon$ інформація, як мобілізуючий чинник соціальної активності. Враховуючи предмет дослідження та відпо- 
відні національні особливості цього складного соціального явища були використані: структурно-функціональний, історично-порівняльний, порівняльно-критичний методи дослідження. Зокрема порівняльно-критичний застосовувався при аналізі існуючих концепцій і версій мобілізації в філософському та історичному контексті. Структурно-функціональний застосовувався в аналізі елементів соціального капіталу, як системи соціальної взаємодії. Історико-порівняльний був використаний у форматі аналізу генези поняття інформаційної комунікації, для відстеження історично зумовлених тенденцій розвитку та змін в суспільстві, в залежності від зростання кількості інформації.

Згідно з вищезазначеною методологією дослідження та завдань наукового аналізу проблеми цього чинника інформація в матеріалах викладена в такій послідовності: Вступ; Людиновимірність інформації та соціальний капітал; Соціотворчість; Мережеві комунікації; Українські реалії; Висновки; Список використаних джерел.

\section{2. Актуальність теми}

Ціла низка теоретичних і методологічних аспектів проблем інформації та інформаційної комунікації пов'язана з проблемою соціального капіталу, та тлумаченням поняття «мобілізація», що в науковому дискурсі є неоднорідним. Залишається він таким і для українського інформаційного простору, проблематика формування якого почала створюватися з кінця 90-х років минулого століття та початку XXI століття. Тому підтвердженням є декілька методологічних підходів, які сьогодні присутні у працях вітчизняних авторів:

Інформаційне суспільство, його суть та тенденції розвитку В. Андрущенко, Л. Губерський, А. Колодюк, В. Кремень, В. Кушерець, I. Надольний, А. Приятельчук, О. Дзьобань $[1 ; 2 ; 3 ; 4 ; 5 ; 6 ; 7 ; 8]$.

Дослідження проблеми інформаційно-комунікативного простору в соціокультурному житті суспільства: В. Крисько, В. Машликін, I. Мельник, Г. Почепцов [9; 10; 11; 12; 38].

Методологічні, соціоепістемологічні, аксіологічні аспекти дослідження феномену інформації як основної складової системи комунікації представлені працями: В. Аксьонової, М. Кузнєцова, М. Санакуєва $[13 ; 14 ; 15]$. 


\section{3. Людиновимірність інформації та соціальний капітал}

Перш ніж розглянути соціотворчий потенціал інформації, варто звернути увагу на питання щодо людиновимірної сутності інформації та тих обрисів, яких вона набуває за умов сучасності. Людиновимірність інформації йде поруч 3 поняттям «соціальний капітал». Соціальний капітал має символічний характер та вписується в структуру інформаційного суспільства. По суті він $є$ його невід'ємною частиною. Звернувшись до історії поняття, не можна не згадати автора цього терміна - П. Бурд’є. Під поняттям «соціальний капітал» він розуміє груповий ресурс, який формує соціальні зв'язки та збагачує суспільство. Це певний шлях встановлення солідарності між різними соціальними групами, а також взаємозв'язків та відповідно до цього взаємозалежностей. Даний процес послаблює нормативне регулювання суспільних процесів та знімає необхідність постійного фіксування домовленостей. П. Бурд’є стверджував: «Соціальний капітал - це сукупність актуальних та потенційних ресурсів, які використовуються надійною мережею учасників або інституціолізованих відносин взаємного знайомства та визнання» [16].

Своє продовження концепція людиновимірності інформації знаходить і у творчості Дж. Коулмана. Останній зауважує, що соціальний капітал створюється з певною метою, а саме - отриманням користі. Соціальний капітал в даному випадку не виникає на порожньому місці, а базується на певному соціальному контракті, що передбачає в свою чергу наявність певних норм та взаємовідносин обміну. Подібні суспільні відносини просякнуті атмосферою довіри, що дозволяє уникати бюрократизму. Крім того, до важливих рис соціального капіталу, за Дж. Коулманом, слід віднести його моральну нейтральність. Свою моральну характеристику даний вид капіталу отримує в процесі використання завдяки методам. Такими методами можуть бути будь-які засоби, що здатні формувати довіру, зокрема «облік добрих справ», своєрідні «кредити», що зближують людей та роблять їх взаємозалежними. Зокрема, Дж. Коулман підкреслював: «Соціальний капітал визначається його функцією. Це не проста сутність, але безліч різних сутностей та мають дві загальні характеристики: всі вони містять в собі той або інший аспект соціальної структури, і всі вони посилюють певні дії людей, що знаходяться в цій структурі» [17]. 
Інший видатний мислитель Р. Патнем дав таке визначення соціальному капіталу: «зв'язки між індивідами - соціальні мережі та норми взаємності, які з них (із мереж) виникають». Але як відрізнити соціальний капітал від інших близьких понять? «В той час як фізичний капітал має відношення до фізичних об'єктів, а людський капітал співвідноситься із особливостями окремих особистостей, соціальний капітал торкається зв'язків між людьми - соціальних мереж, норм взаємодії та довіри, що виникають в таких відносинах. В цьому смислі соціальний капітал тісно пов'язаний з тим, що ми називаємо «громадянською гідністю», гідністю особистості, а отже людиновимірністю. Але остання найкраще проявляє себе саме в мережі соціальних взаємовідносин. Суспільство багатьох гідних проте ізольованих особистостей зовсім необов'язково $є$ збагаченим соціальним капіталом» [18].

Таким чином, Р. Патнем запропонував модель соціального капіталу, до якої увійшли такі вже перелічені елементи як: 1) соціальні мережі, 2) соціальні зв'язки та 3) довіра. Останні два елементи є соціально-психологічними характеристиками людини. Перший ж елемент $€$ ключовим у характеристиці «соціального капіталу» (в чому ми пересвідчилися вище) та входить до безпосереднього предмета нашого дослідження. Отже, у нас є достатні підстави стверджувати, що інформаційний простір є складовою соціального капіталу. Останнє також вказує на його людиновимірність. Водночас одним із найважливіших елементів соціального капіталу є соціальні мережі, сутність та роль яких спробуємо з'ясувати [19].

Як зазначає I. Мачерінскене, соціальні зв'язки - це клей, що поєднує і утримує в собі всі елементи. Проте самі по собі зв’язки не можуть називатись «соціальним капіталом». Називатись так вони можуть лише за умови ефективного використання [20].

Отже, можна виділити кілька важливих рис людиновимірності інформації:

1) Доцільність. Під нею насамперед мається на увазі не множинність зв'язків, а можливість завдяки цим зв'язкам привести людину до досягнення поставленої мети;

2) Свідомість. Свідоме ставлення суб' єкта соціальних відносин до того як і чим він користується, навіть якщо спільнота не надає йому 
явних преференцій. Останнє не означає неефективність, а швидше означає низку переваг, які не усвідомлюються самою спільнотою;

3) Формування на основі вже існуючих соціальних структур. Соціальний капітал формується в певних соціальних структурах і $є$ джерелом реалізації певної мети [17].

Зважаючи на особливості соціального капіталу, його, на нашу думку, можна пов'язати з таким поняття як «соціальна мережа». Вже згаданий вище Р. Патнем вважає, що соціальні мережі - це міжособистісне спілкування, яке $є$ громадянським обов'язком. Найголовнішими $\epsilon$ горизонтальні мережі, а не вертикальні, тобто такі, які будуються за спільним інтересом, саме вони формують соціальний капітал. Тому особливо важливим в даному проблемному полі нам видається перехід від людиновимірності до креативного капіталу особи та суспільства, до функції соціотворчості та ролі інформації в цьому процесі. Соціальний капітал грунтується на постійних та міцних зв'язках, проте глобалізований світ в інформаційну епоху все менше використовує подібні зв'язки. Соціальні зв'язки XXI ст. мають змінний, ситуативний характер. У праці американського економіста Р. Флоріда «Креативний клас: люди, які змінюють майбутнє» такі зв'язки названі послабленими. Ïх перевага над постійними зв'язками полягає в великій кількості та меншій затраті часу на їх встановлення $[19 ; 21]$.

Ці зв’язки є ключовими для мобілізації людських ресурсів та підживлюють креативну атмосферу міста. Проте подібна ключова роль послаблених зв'язків для історії вже давно помічена цілою низкою видатних мислителів. Так, В. Беньямін в 30-х рр. XX ст. процитував поліцейський рапорт 1798 року, де автор висловлював жаль 3 того приводу, що ефективний нагляд над громадянами більше неможливий: «кожна людина не знайома $з$ іншою, ховається в натовпі і ні перед ким не червоніє». Також не можна не помітити, що подібне висловлювання якнайкраще розкриває і принцип побудови висловлювань у всесвітній мережі. Також Бодлер, розмірковуючи над життям у Парижі наприкінці XIX ст., назвав його місцем фрагментарних зустрічей, незнайомців, натовпу, де люди можуть відволіктися від «внутрішніх суб'єктивних демонів». Бодлеру не подобався натовп, проте він любив свободу і «можливості для анонімності та допитливого спостереження» [22]. Отже, подібні процеси носять креативний 
характер і надають соціальним мережам як вагу певної значущості, так і яскраво вираженого негативу.

\section{4. Соціотворчість}

Але що таке соціотворчість або соціальна творчість? Якщо звернутись до теоретичного підгрунтя поняття «соціальної творчості», не можна не згадати про Р. Оуена, засновника утопічного соціалізму. Цей англійський мислитель ще у XVIII ст. висловив низку актуальних тверджень. Р. Оуен визначив соціальну творчість як ненасильницьке створення людьми нових форм організації власного життя у відповідності iз власними переконаннями [23].

В Енциклопедії соціології знаходимо таке визначення соціальної творчості: «Вища форма соціальної діяльності, творчий процес, спрямований на перетворення і створення якісно нових форм соціальних відносин і суспільного буття». В іншому словнику «Економіка та соціологія праці. Список термінів» зустрічаємось 3 розширеним підходом: «найбільш зріла форма соціальної активності, вища форма соціальної діяльності, творчий процес, спрямований на перетворення існуючих та створення якісно нових соціальних відносин та соціальної дійсності. Вона передбачає мобілізацію всіх інтелектуальних, духовних та фізичних сил, дозволяє особистості максимально повно розкрити свої здібності, спрямувати енергію на досягнення інтересів суспільства, колективу» [24; 25].

Можна стверджувати, що саме інформація стає мобілізуючим чинником для соціальної творчості та насамперед спонукає соціальну активність. Крім того, в основі соціотворчості лежать процеси комунікації. Так, на думку російського вченого Ф. Мінюшева, соціальна творчість - це насамперед творення вищих цінностей та ідеалів, принципів, а також символічних комунікативних засобів, таких як міміка, жести та мовлення як таке. Тут також можна навести слова й іншого російського мислителя С. Срмакова: «Ми виходимо з того що соціальне - це завжди про взаємодію між людьми і про ситуації, які стаються через цю взаємодію» [24; 25].

Деякі дослідники відносять названі нами характеристики до функцій соціальної творчості, серед яких: 1) функція перетворення (шлях конкретних бажаних змін); 2) комунікативна функція (насамперед від- 
повідає за процеси культурної ідентичності та дозволяє зберегти та передати культурну традицію); 3) функція анімації (означає фактично суспільну активізацію, «пожвавлення» від лат. аnima - «душа», «стимулювання до дій») [25; 26].

Сучасні інтернет-технології забезпечують два важливих для соціотворчості аспекти: 1) сприяють зростанню індивідуальної та групової комунікації; 2) здатні спрямовувати потоки комунікації в той чи інший напрямок. Назване вище впливає на трансформацію соціальної структури суспільства і водночас виводить комунікацію за межі економічного базису суспільства. Це дає можливість для формування громадянської позиції, відкриває простори для свободи і, відповідно, для творчості.

Розглянемо можливості функціонування соціальних груп в Інтернет-мережі. Перелік таких можливостей може мати наступний вигляд:

- Здешевлення. Через здешевлення комунікацій значного спрощення зазнає процес формування організацій будь-якого масштабу, значна економія на видатках зі створення та підтримки ресурсів;

- Децентралізація. Через децентралізацію відбувається зростання можливості соціального проектування;

- Відсутність цензування. 3'являється можливість формування спільнот за будь-яким цензом - віком, статтю, професією, освітою і т. ін.

- Некомерційність. Новим цікавим утворенням є спільноти некомерційного спрямування - наукові, просвітницькі, правозахисні, політичні, розважальні.

Саме цей останній вид суспільних утворень стає реальним осередком інституцій громадянського суспільства, а, відповідно, і прямої демократії.

Слід зазначити, що динамічність $є$ характерною рисою соціуму і законом його розвитку. Особливого динамізму суспільство набуває за часів кризи. В такій ситуації суспільство як живий організм починає оновлювати «клітини». Слід з'ясувати, що стимулює інноваційні процеси. Ми висловили припущення, що таким каталізатором $є$ інформація, проте не вся інформація, а лише та, що підживлює і формує креативний капітал. В іiі основі лежить специфічний когнітивний метод, що виробляє у суб'єкта внутрішню потребу у продукуванні нового знання, а точніше продукуванні почуття цікавого. 
Вироблення почуття цікавого не є еквівалентним виробленню цікавості до чогось конкретного. «Когнітивні методи спрямовані на розвиток і удосконалення механізмів рефлексії суб'єкта навчання і спонукання в ньому креативності» [26].

Водночас, на думку К. Сєргєєва, будь-яка догма скорочує простір цікавого. Цікаве є над тривіальним та протилежним очевидному. Цікавим є те, що вислизає, рухається, звільнює мислення людини. Навколишня дійсність побудована за бінарним принципом. В даному випадку ми матимемо дихотомію усвідомленого-неусвідомленого, загадкового-очевидного. Очевидність нагадує соти, в яких розміщається будь-який предмет, що піддається осмисленню. Таке розміщення неодмінно тягне за собою негативні наслідки, а саме: втрату свободи, оскільки предмет осмислення потрапляє на конкретне відведене йому місце [26].

Перевага цікавого на противагу осмисленому полягає у наявності свободи, що забезпечується відсутністю ієрархії. Відповідь на запит цікавості переводить його в площину тривіального. Але що $є$ однозначно нецікавим і яка площина дії цікавого? Хаос та повна невпорядкованість не є цікавими, адже остаточно унеможливлюють подальшу рефлексію. Це яскраво видно під час так званих інформаційних війн. Існує декілька визначень інформаційної війни. Але в даному контексті можна скористатися визначенням, що міститься у «Політологічному словнику»: «відкриті та приховані цілеспрямовані інформаційні впливи різних систем одна на одну з метою отримання перемог у матеріальній сфері». Такі інформаційні війни, на нашу думку, здатні викликати цікавість лише на перших етапах, проте згодом суперечлива інформація лише викликає роздратування, а згодом і байдужість [26].

Природною реакцією організму є утримання від надмірної витрати сил там, де дати однозначну відповідь неможливо. Тому реакцією на інформаційну війну є здивування та відчуття сенсації, яке $є$ короткотривалим. Крім того, результативність інформаційних війн, яких можна порівняти із видом пропаганди, залежить від інтелектуального рівня того суспільного прошарку, на які вони спрямовані. 3 іншого боку, не $\epsilon$ цікавим розкладене по полицям, тривіальне. Така інформація $є$ мертвою та не спонукає до подальших інтелектуальних пошуків. Важливо також зазначити про межі тривіальності, які розширюються із швидкі- 
стю циркуляції інформації. Від рівня насиченості інформаційних просторів буде залежати і їх оригінальність. Людина, яка сприймає численні інформаційні потоки з часом адаптується та звикає. Все менше залишається того, що здатне щиро дивувати. Звідси і бажання інформаційних каналів вразити та епатувати читацьку чи глядацьку аудиторію. Крім того, важливим є і новизна інформації, оскільки остання здатна викликати почуття цікавого та вражати лише в перший момент iii отримання. Повторення і багаторазовість не грають ні на користь інформації, ні на користь того, хто є iї джерелом. Отже, подібна інформаційна політика здатна викликати лише зворотній ефект. Але цінність інформації в цьому сенсі якраз і полягає в суцільній новизні.

Ще одна риса інформації, яка трансформує останню в цінність в XXI ст. - це важкодоступність. Отже, все, про що ми писали вище, не утворює когнітивного дисонансу, оскільки, як з'ясувалося, не вся інформація може мати ціннісний характер та формувати креативний капітал, а лише та, що викликає інтерес та є нетривіальною. Відповідно, дана інформація не знаходиться на поверхні та підлягає детальному пошуку.

Спираючись на останні дослідження у філософії інформації, детальніше розглянемо властивості інформації, які сприяють соціотворчості. Їх перелік, на нашу думку, може виглядати наступним чином:

1) повнота - під повнотою мається на увазі змога на основі інформації зробити вибір або прийняти рішення, а також виконати конкретну дію;

2) достовірність - визначається смисловим змістом інформації, джерелом інформації та обставинами. Слід сказати, що в умовах інформаційних війн, про які ми писали вище ця риса стає проблемою. Вирішити дану проблему можна шляхом репрезентативності, грунтовного шляху аргументів, фактів, речових доказів і т. ін.

3) доступність інформації/важкодоступність/недоступність - ця риса, як уже зазначалося, часто знаходиться на одних вагах із цінністю і залежить від цілей поставлених перед шукачем інформації;

4) складність - визначається смисловою структурою інформації та змістом як окремих структурних одиниць, так і всієї інформації в цілому;

5) важливість - ця риса є релятивною по відношенню до суб'єкта, адже визначається індивідуально і залежить від багатьох чинників. 
Людина як суб'єкт сама надає ярлики інформації так, як «корисна», «цікава», «важлива». При цьому важлива інформація як правило підлягає збереженню, а неважлива не обов'язково.

6) актуальність - визначається часом появи інформації. Якщо інформація з'являється перед настанням певної події або щойно після того, як вона відбулась і може бути використана, тоді вона є актуальною. Інформація, яку отримано після того, як вона могла бути використаною вважається неактуальною;

7) зрозумілість - визначається готовністю реципієнта до її сприйняття [26].

Отже, всі ці риси складають цінність інформації, а іiї (цінності) першою вихідною умовою $є$ новизна як невідомість до моменту отримання.

Отже, повернемося до соціокреативних процесів, що розгортаються в соціальних мережах. Таке утворення як «соціальні мережі» належить до неформальних факторів є каталізатором інноваційних процесів. Специфіка даної соціотворчості полягає в особливому статусі «соціальних мереж», які виходять за межі традиційної інституалізації суспільства. Це певна «система антисистеми». Пояснимо цей парадокс.

Незважаючи на випадіння зі стандартних інституційних правил, спільноти соціальних мереж - це система, що об'єднує атомарних індивідів. Атомарність тут насамперед визначається відмінністю у віці, соціальному статусі, і навіть географічному розташуванні. Антисистемність полягає насамперед у знятті географічних меж, простоті вступу та виходу зі спільнот, спрощеним правилам членства. Це така структура, що існує паралельно традиційній. Ї̈̈ ієрархія є динамічною та залежить від членів так само, як члени спільноти від їі керівництва. Динамічність підтримується наданням важливої та актуальної інформації з обраної тематики. Відбувається розвиток ініціативи в умовах «живої» конкуренції.

\section{5. Мережеві комунікації}

Отже, що ж таке соціальні мережі? Незважаючи на надзвичайну популярність цих інформаційних та комунікаційних ресурсів серед користувачів мережі Інтернет, дана тема є малодослідженою. Можна лише припустити, що дослідження цього складного феномену потребує надзвичайних сил та інноваційних ресурсів саме для того, щоб їх 
дослідження не перетворилося на декларативні заяви. Нам вдалось відшукати кілька актуальних, на нашу думу, досліджень.

Вже згаданий нами вище К. Сєргєєв вважає, що соціальні мережі це сукупність індивідів, що володіють розподіленим, «децентралізованим ресурсом»; сам факт розподілення ресурсу стає перепоною для утворення жорсткої ієрархії. Даний розподілений ресурс в свою чергу $\epsilon$ спільною власністю. Іншими словами можна охарактеризувати цей процес так: «індивід, що отримав доступ до однієї з «точок» мережі, автоматично отримує можливість доступу до всіх ресурсів, що містяться в даній мережі. Отже, говорячи як про ресурс, який вільно розподіляється в нашому випадку ми матимемо на увазі креативність [26].

Згідно з іншими версіями, соціальні мережі - це соціальна структура, що складається 3 вузлів, якими виступають соціальні об'єкти (соціальна група, індивід). Соціальні мережі - це інтерактивний вебсайт суспільного користування, конвент якого наповнюється самими учасниками мережі. Наголошується на слові «самими», що ще раз підкреслює самоорганізацію та шлях до саморозкриття творчих амбіцій індивідів [26].

Серед всього функціонального різноманіття соціальних мереж, яке може бути предметом окремого дослідження, нас цікавить саме мережа як середовище формування цікавого та як середовище формування громадянського суспільства.

У чому проявляється креативність соціальних мереж? Оскільки, як вже було з'ясовано, інформація набуває цінності за умови ії подальшої передачі та використання. В такому сенсі інформація стає на сторожі онтології, оскільки має змогу зберігати та передавати унікальні, різноманітні прояви буття. Сама унікальність та виключність проявів буття в свою чергу також пов'язана з неоднорідністю розподілу матеpiï, енергії та інформації в просторі та часі, їх різною активністю в тих чи інших умовах.

Відносно так званих спільнот, то згідно з дослідженням, проведеного Сажиною В., вони характеризуються таким чином:

1) малі спільноти одночасно є і суб' єктом, і об'єктом процесів формування і накопичення соціального капіталу;

2) малі спільноти є найбільш продуктивною формою соціального капіталу порівняно з іншими формами; 
3) малі спільноти потребують особливих інституціональних умов, що побудовані за принципом самоорганізації.

Крім того, на нашу думку, буде корисним проаналізувати і основні принципи комунікації в соціальних мережах. Як свідчить аналіз вони наступні:

1) Принцип очікування. Очікування - проявляється в тому, що у кожної людини є бажання отримати реакцію на власну діяльність у мережі. Як стверджують психологи, таку реакцію слід вважати нормальною, адже в реальному житті за свої дії людина також очікує реакції та отримує іiі. Але тут є одне «але»: в реальному житті на людину, як правило, чекає миттєва реакція (на пряме запитання людини «у вічі» слідує відповідь), а реакція у віртуальному світі перетворюється на суцільне очікування, що збільшує тривогу та фрустрацію (неможливість зосередження);

2) Принцип часу. У зв'язку із першою рисою пов'язана і друга риса - час очікування. Час очікування може бути абсолютно різним: короткотривалим та довготривалим, а також таким, що призводить до досягнення мети або безрезультатним;

3) Принцип великої кімнати. «Велика кімната» - ефект присутності «друзів» неначе в одному домі, де всі учасники займаються своїми справами, а час від часу виходять у центр кімнати для викрикування якихось важливих речей. У відповідь людина може отримати схвалення або, наприклад, не отримати нічого. Внаслідок цього, у останньої з'являється напруження від невизначеності та ігнорування, з'являються сумніви чи поміченою залишилась активність. Далі ж виникає бажання повернутися у «велику кімнату» для перевірки, оскільки у людини формується низка незакінчених гештальтів (низка неотриманих реакцій);

4) Принцип незнання. Незнання пов'язане $з$ тим, що повний смисл повідомлення, яке передається, втрачається. Мається на увазі, що втрачається цілий пласт невербальної комунікації, адже під час традиційного спілкування людина отримує ряд «знаків» - жести, міміка, погляди. У повідомленнях є ризик буквального розуміння, що в подальшому тягне за собою непередбачувані наслідки. Непередбачуваність, народжена цією невербальною відсутністю, формує багатозначність розуміння. Відчувається неможливість повноти почуттів 
та думок. 3'являється відчуття недомовленості не через не промовлені слова, а через безрезультатне бажання вкласти в повідомлення «живі» емоції;

5) Принцип невизначеності. Невизначеність, яка народжує хибні уявлення про людей та ситуації непорозуміння за ситуації відсутності повної картини події. Все це зазвичай породжує домисли та інтерпретації;

6) Принцип синхронізації. Синхронізація людських станів та настроїв. Готовність до спілкування - саме ця «опція» соціальних мереж дозволяє уникати насилля в спілкуванні та обирати зручний відповідно до бажання людини. Як зазначав М. Мамардашвілі в «Лекціях про Пруста»: «Якби Марсель відправив листа замість того, щоб кидатись в обійми - ймовірно його мати знайшла б і час, і настрій, відповісти на лист належним чином» [27].

7) Принцип стану. Стан онлайн та оф лайн - самі ці стани у віртуальному світі вважаються показовими. Дуже часто знаходження онлайн і відсутність спілкування розцінюються як зневага та ігнорування, хоча, стан онлайн свідчить лише про те, що у людини увімкнений комп'ютер, а стан оф лайн не є доказом відсутності людини вдома чи в будь-якому конкретному місці. Це $\epsilon$ справжньою проблемою для сучасної комунікації адже ці поняття дуже часто ототожнюються.

На основі вже зрозумілих принципів спілкування у соціальних мережах, здійснено спробу визначити особливості функціонування груп спілкування та правила, за якими це спілкування відбувається. Аналіз показує, що між групами спілкування існують три типи зв'язків: 1) я і інший; 2) я і друзі; 3) я та інші. Першим двом типам притаманні всі функціональні можливості соціальних мереж. Для третього типу - лише повідомлення. Подібна структура дає підстави до побудови у майбутньому соціальної мережі, яка б об'єднувала мінімум осіб.

До безпосереднього виразу творчості особистості у соціальних мережах існує так званий «новий формат історії». Під «форматом» мається на увазі створення короткого повідомлення, яке б було максимально коротким за змістом та глибоким за сутністю. Повідомлення, створене таким чином, містить низку особливостей, зокрема здатні- 
стю смислового поширення в різні напрямки та динамізмом змін. Кожне повідомлення story може поєднуватись у ланцюг з наступними шляхом бокових асоціацій. Таким чином утворюються розгалуження смислів, по яким можна здійснювати мандрівки. Дослідники порівнюють даний формат 3 живим клубком. Такий клубок здатен передати враження та з'єднати їх в один часовий континуум, де проведена лінія між минулим, теперішнім та майбутнім [27].

Одним із лейтмотивів комунікації в соціальних мережах є бажання передачі складної емоції, проте не може бути задоволеним повною мірою через брак засобів. Складні емоції можуть передаватись через прилучення до творів мистецтва. Останні є шляхом до катарсису, до зміни внутрішнього єства та світу. В іншому сенсі через твори мистецтва людина вчиться бути людиною, шукає «надприродних» станів, які дозволяють трансцендентувати себе у вічність. Можна простежити такий «мистецький шлях» через численні доробки художників, дизайнерів, режисерів, музикантів, які щодня розміщаються в соціальних мережах.

Як свідчить історія філософії, спроби вивести істину виключно логічним шляхом є приречені. Згідно 3 уявленнями стародавніх греків, зокрема Сократа, істина може бути лише виведеною, тобто відбутися як певний результат логічних операцій. За таким самим принципом будується і медіапростір. Його сутність полягає в тому, щоб із численних протиріч сформувати у людини єдине, істинне бачення проблеми. Проте тут є ціла низка труднощів, які пов'язані як $з$ особистісним рівнем розвитку особи, так і $з$ ілюзіями, або, вдаючись до термінології історії філософії «примарами людського роду», що заважають самостійному виведенню істини та критичному мисленню як такому. Для подолання цих недоліків існує систематизуюча або атракторна властивість інформації, яку ми розглянемо далі.

Отже, на підставах аналізу можна зробити частковий висновок - інформація перетворюється у соціальний капітал тільки за умов існування ефективної соціальної мережі і зв’язків, що постійно підтримуються. Саме цей чинник визначає основу для появи поняття людиновимірності інформації, якій притаманні низка властивостей: доцільність, свідомість, мета. 


\section{6. Українські реалії}

В інформаційній комунікації функціональний підхід характеризується переконаністю у відмінностях комунікації від спілкування. Згідно $з$ цим підходом, вважається, що комунікація є частиною професійної спрямованості, оскільки передбачає цілу низку операцій із інформацісю. Передусім йдеться про збір інформації, іiі збереження та поширення. Зрозуміло йдеться і про вплив на масову свідомість за допомогою різноманітних технологій. Загалом інформаційна комунікація які соціальна комунікація здатна впливати на наповнення інформаційного державного простору певним змістом. На думку В. Різуна, соціальні комунікації формують інформаційний простір держави та визначають іiі інформаційну політику, чим і впливають на систему прийняття рішень людьми, державними інститутами та владою [29].

Представником атрибутивного підходу є 3. Партико. Намагаючись визначити поняття «інформація», дослідник наголошував, що інформація - це розпізнані образи, які кібернетична система зберігає в пам'яті. Автор даного підходу вважає, що інформація має лише кібернетичний вимір, а ії одиницею виміру є біт [30].

Окремо слід згадати і про Києво-Могилянську школу філософії, пріоритетом для якої є вивчення соціальної комунікації. Один із головних представників цієї школи - С. Квіт. Наслідком глобалізації, на його думку, є уніфікація засобів масової інформації. У нових глобалізаційних умовах засоби масової інформації, що утворюються не здатні відповідати на запити соціальних рухів. Дана позасоціальність піддає сумніву і демократичність нових медійних утворень. С. Квіт зазначає, що будь-яка інновація спонукає різні групи, що ведуть боротьбу за владу, використати їх самим з цією метою, а не заради суспільного інтересу [31].

Протилежної думки дотримуються запорізькі та львівські вчені, a саме: В. Буряк та Й. Лось. Вони вважають, що західноєвропейська глобалізаційна модель не є прийнятною для України, оскільки $\epsilon$ наслідком масових комунікаційних процесів, а не навпаки. Для українського суспільства це не може принести користі та відводить напрямок розвитку України в неефективне русло. Це призводить до того, що вище названі вчені приходять до думки про інформацію як публіцистику [32; 33]. 
Й. Лось вживає відповідний термін, який звучить як «світоглядна публіцистика», і під цим він безпосередньо має на увазі саме «інформацію». Можна погодитись 3 даною позицією, оскільки глобалізація за такою логікою є достатньо шкідливим феноменом, то доречним може бути лише формування та поширення «національно-світоглядної публіцистики», яка б несла національну ідею [33].

Іншої думки притримується науковець М. Житарюк, погоджуючись $з$ позицією світоглядної публіцистики (Й. Лось), він відзначає подібний вид комунікації як добре розвинений в Україні та притаманний ій традиційно, світоглядна публіцистика здатна зробити внесок у розвиток соціальних і духовних інститутів України, таких як релігія, політика, наука, література [28; 33].

Загалом група львівських науковців приходить до висновку про важливість управлінських феноменів у сфері комунікації, що повинні мати свої прояви в національних інтересах України, а також в індивідуальних та групових інтересах. Управління в сфері мас-медіа спрямовує і державну політику, і державну стратегію загалом. Крім того, зазначені вище вчені вбачають пряму залежність удосконалення засобів масової інформації та демократизації суспільства. Світоглядна публіцистика в цьому контексті може відігравати насамперед просвітницьку роль, але це приховує певні небезпеки (наприклад перетворення ії на обслуговування тієї чи іншої ідеологіï).

Існують певні загрози впровадження даної моделі, зауважує київський вчений Г. Почепцов, але його погляд не відрізняється фаталізмом. Він вважає, що від маніпуляцій світоглядну публіцистику може врятувати висока громадянська свідомість та усвідомлення всієї цінності справжнього демократичного суспільства. Говорячи про інформацію та їі цінності важелі українські дослідники у галузі інформаційної і соціальної комунікації виділяють такі блоки цінностей:

- Загальнолюдські: життя людини, світ, мир, злагода, справедливість;

- Національні: нація, національна культура, національна політика, єднання і мир у державі (останнє є особливо актуальним в наші дні);

- Етнічні: етнос, етнічна культура, історія етносу.

- Професійні журналістські: свобода слова, правдивість, чесність, солідарність, справедливість, порядність, відповідальність, неупередженість та об'єктивність; 
- Індивідуальні: самовдосконалення, самозбереження, самовідданість, лицарство, шляхетність, відважність, доброта, співчуття, совість та щирість, повага до інших [38].

Серед вищенаведених найважливішою вважається, що саме духовна складова визначає особливості поширення значущої інформації серед населення особливо в перехідні часи. Дуже багато залежить від індивідуальних рис транслятора інформації, особливо від його неупередженості, справедливості та сміливості. Все це з необхідністю має підкріплюватись гарантованою державою свободою слова.

На жаль, за умов недотримання свободи слова де-факто здійснювати процеси успішної комунікації для розбудови держави стає достатньо важким завданням. Що стосується юридичного боку даного питання, то свобода слова закріплена у законодавстві України. Крім того, важливим кроком в демократизації інформації є можливість доступу до неї на будь-яких урядових порталах. Особливої уваги заслуговує питання про цензуру в українських засобах масової інформації, відсутність якої також гарантується законодавством України.

Існування особливих тем «на замовлення», що є логічним продовженням відсутності громадського мовлення та наявності приватних засобів масової інформації. Варто наголосити, що подібна ситуація $\epsilon$ ефективною у інформаційних війнах, а також у прикритті недобросовісної політики та криміногенної обстановки в державі.

Індивідуальні риси транслятора інформації, саме як складової, залишають бажати кращого особливо в умовах зростання різноманітного «чорного піару» та нехтуванням основних соціальних принципів таких, як чесність та справедливість. Відповідно мова може йти лише про зростання громадянської свідомості серед тих хто доносить цю інформацію до споживача.

Особливо небезпечною є тенденція до пропаганди насильства, в тих засобах масової інформації, які намагаються неупереджено подавати інформацію українському суспільству. Через недемократичні процеси всередині країни почастішали випадки насильства та погроз журналістам, про що свідчать численні репортажі та статті про резонансні вбивства. Висвітленню даної теми надається особлива увага в суспільстві, це відбувається через те, що процес соціальної комунікації та поширення інформації, є дзеркалом суспільних та економічних 
відносин в країні. Тому напади на журналістів є свідченням зростання нетерпимості та нетолерантності в суспільстві.

Ряд українських вчених вважають, що є всі підстави щоб розвивати в Україні публіцистичну журналістику, і для цього є суттєве інформаційне підгрунтя. Розвиток цього нового напрямку в сфері соціальної комунікації, варто починати з світоглядної бази.

Наприклад, В. Буряк вважає, що такою основою може бути інформаційно-художня свідомість, що спонукає до образного сприйняття інформаційного світу та базується на міфологічних архетипах. Останнє створює сприятливі умови для формування філософсько-концептуальних основ суспільної свідомості. Водночас В. Буряк віддає перевагу онтологічним та генетичним основам комунікації на противагу іiі соціальним складовим. Основний акцент, на думку вченого, потрібно робити на інтелектуалізм та інтенсивність різножанрової інформації. Можна стверджувати, що дискурс між національним та глобалізаційним напрямом розвитку засобів масової інформації може стати пріоритетним в наукових дослідженнях інформації [32].

Як вже зазначалося, існує два основних методологічних підходи (функціональний, атрибутивний) до вивчення комунікативних процесів, але й існує й ще один, компромісний - підхід методологічного плюралізму. Представниками цього підходу є Б. Потятиник, В. Владімиров, Ю. Фінклер [34; 35; 36].

Зокрема, Б. Потятиник пропонує концепцію «феноменологія масової комунікації» [34]. Подібний напрямок бере за основу множинність реальностей, кожна $з$ яких формується за провідним когнітивним стилем. Отже, мова йде не про кінцеву мету доведення інформації до суб’єкта комунікації, до якої потрібно прагнути, а про співіснування інформаційних смислів. Не зважаючи на те, що у даного виду феноменології відсутня якась ієрархія інформаційних смислів, головною ідеєю $\epsilon$ теза про те що, привілейований статус в бутті суспільства має сфера повсякденного життя, в якій інформація створюється і циркулює.

Прихильники даного підходу вважають, що для сфери повсякденного життя характерно тягнутись до комунікативної гармонії. Автор даної концепції пропонує розглядати комунікаційні процеси в традиційному феноменологічному руслі, тобто розглядати текст, виходячи iз них самих, а не з існуючих інтерпретацій ретрансляторів, як вторин- 
ного матеріалу. Згідно з логікою даного розмірковування, текст як проект $є$ вільним утворенням, здатним самостійно розвиватися, єдиною перешкодою в цьому процесі є обмеженість часовими рамками.

Світова мережа соціальної комунікації (Інтернет), на думку автора $\epsilon$ прикладом вільного утворення, що вносить неоцінений вклад у розвиток світових засобів соціальної комунікації. Описуючи світову мережу (Інтернет) Б. Потятиник загострює увагу на тому, що це «найграндіозніша за всю дотеперішню історію людства споруда, яку сформовано без будь-яких політичних централізованих зусиль» [34].

Можна зробити певне припущення, що на світову мережу комунікації не можливо здійснити жодного впливу, вона виступає оплотом свободи, вільнодумства та прямої демократії. Все це дозволяє Б. Потянику зробити глобальний, а не локальний висновок: «Цивілізація це річище, яке сформував потік. Потік інформації. Треба думати про інформацію як про потік, який ніби й незалежний від людства, але мало залежний від кожного з нас» [34].

Із цього випливає питання для подальших дискусій в загальному українському науковому дискурсі головною тезою якого $є$ втрата контролю над інформацією, особливо над тією яка повинна бути соціально-оріснтованою.

Дослідженням герменевтичних аспектів інформаційно-комунікаційних процесів займається В. Владімиров, він пропонує звернути увагу на те, що масова комунікація не несе загрози суспільним процесам, а радше навпаки сприяє зміцненню суспільного устрою та його ціннісному наповненню. Сам процес соціальної комунікації виглядає як шлях від масової комунікації до самопорозуміння. Все це «веде до соціального прогресу». Ми не можемо зі свого боку не звернути увагу на актуальність подібних тверджень у зв'язку з останніми подіями в Україні. Можна констатувати, що активна масова комунікація призвела до зростання колективного духу, а останнє призвело до позитивних та конструктивних перетворень, а також до зміцнення духу колективної солідарності [35].

Якщо глибше проаналізувати проблему зміцнення соціального устрою та ціннісного виміру соціальної комунікації, то варто зосередитись на іiі структурних особливостях, де особливу роль відведено взаємовідносинам влади медіа та влади політичної. Досліджуючи соці- 
альну комунікацію не слід забувати, що і медіа, і політика - це впливові соціальні інститути, що не можуть не впливати один на одне, і водночас на суспільство. Тому функціональний зріз обох інститутів суспільства потрібно досліджувати саме в актуальному спрямуванні, так би мовити, модернізованому вигляді, розуміючи цю пряму взаємозалежність [36].

Звичайно, не можна обмежуватися існуючими підходами у дослідженнях сучасних українських дослідників, адже потрібно вчасно відповідати на виклики сучасності. Особливо необхідним перегляд цих досліджень постав в умовах радикальних прагнень українців. Також варто зауважити, що це стане можливим лише після вироблення інформаційної стратегії, яка могла б базуватись на тих цінностях про які ми писали вище. Необхідність вироблення поділеної стратегії можливо за використання інтелектуальних ресурсів, представлених географією всієї України. В світлі останніх подій зросла важливість інформаційної політики, але не тільки іiї вироблення, але й захист та пропагування.

Основою майбутнього стратегічного дискурсу в галузі інформаційної політики може бути лише вироблення конвергентних процесів та сприяння поширенню когнітивних ресурсів. Якщо ж узагальнити напрями, в яких потрібно рухатися для вироблення основних принципів інформаційної політики, то можна дійти до таких висновків (спираючись на дослідження фахівців у даній галузі, зокрема у дослідженні формування бібліотечних ресурсів):

1. Інформація, яка отримана споживачем шляхом документування або вербалізованого отримання, не може повною мірою дорівнювати вихідній інформації, тобто не може бути ӥй тотожною. Втрати на цьому шляху є неминучими, що у філософії інформації прийнято називати ентропією.

2. Утворення та розповсюдження когнітивних ресурсів здатне применшити ентропійні процеси. Когнітивні ресурси - це ресурси, що здатні не просто повідомляти факти, але й наводити відомості про автора даного повідомлення (різноманітні біографічні відомості), а також наводити категоріальний апарат тієї чи іншої галузі про яку йде мова у повідомленні чи статті.

3. Все це може втілюватися завдяки процесам конвергенції, які реалізуються в наукових бібліотеках України, наприклад такої як бібліотека ім. В. Вернадського [10]. 
3 цього випливає, що діалогічний зв'язок суспільства й культурна політика держави повинні перебувати у тісному зв'язку для ефективного зростання громадянської свідомості та впровадження тих цінностей журналістської етики, про які йшлося раніше. Отже, ми маємо і проаналізувати ідею громадського телебачення, яке вже почало втілюватись на наших теренах (зокрема в деяких інтернет проектах, що набули поширення під час революційний подій в Україні наприкінці 2013-2014 років). Громадське телебачення дозволяє змінювати інформаційні потоки, їхню смислову спрямованість: від обслуговування державного апарату, комерційних показів іноземного контенту до дійсно ціннісних складових інформації. Змістове наповнення таких потоків може бути надзвичайно важливим та об'єднуючим чинником для всієї країни. Можна сказати, що відсутність прямої комерційності дає шанс для численних дитячих, підліткових та молодіжних програм, адже саме вони здатні формувати свідомість молодих українців. Це шанс і для програм культурного та просвітницького спрямування, брак яких в Україні $є$ катастрофічним. Наслідком відсутності подібної інформаційної політики є сприятливий грунт для різноманітних маніпуляцій та необдуманих дій. Програми громадського телебачення в прямому сенсі могли б сприяти розвитку української ідентичності нового зразка, яка б не «застрягала» в ностальгічному минулому, а відкривала перспективи майбутнього, спираючись на традиційні основи суспільства. Тому насамперед ці традиційні основи суспільства потрібно відшукати, систематизувати, а потім продемонструвати українському народу. Адже знання та пам'ять $є$ складовими формування цієї ідентичності.

Крім того, в руслі інформаційних новацій абсолютно необхідним $є$ і поширення загальнолюдських надбань, а також «рекламування» багатої української культурної спадщини. Зокрема, саме на це спрямована діяльність кількох міжнародних культурних фестивалів в Україні. Їхня ефективна робота може свідчити лише про правильність подібного шляху та потребі збільшення таких культурних акцій з акцентом на інформаційно-світоглядний обмін. Свропейськість України має бути донесена до всього світу та насамперед до населення України, що в силу важких історичних умов цю європейськість намагаються відкинути. Європейське коріння України має бути продемонстроване саме завдяки новим засобам масової інформації. 
Зокрема як аргумент цих змін, вчений Г. Почепцов стверджує: «У країнах СНД недостатній розвиток зв'язків з громадськістю можна пояснити тим, що в них ще немає необхідного рівня залежності влади від населення. Ми маємо гіпертрофований зв'язок, що відображає залежність населення від влади, і слабкий зворотній зв'язок» [38].

Продовжуючи розмірковувати в тому ж напрямі дослідник В. Королько: «Суспільство опинилося в стані низького рівня взаємопорозуміння та конструктивної взаємодії між державними органами влади, їх управлінськими структурами, політичними партіями i громадськими формуваннями, підприємницькими, комерційними та іншими новими інститутами ринкового типу. Конфронтаційний характер відносин між ними пояснюється відсутністю у кожного 3 цих інститутів прагнення чітко сформулювати свої інтереси і загальногромадську значущість власної діяльності, налагодити співробітництво між собою заради загальнодержавних, загальнонародних інтересів у часи історичних випробувань, що випали на долю України» [39].

Підсумовуючи вищеперераховане приходимо до узагальнення, причини занепаду ціннісних основ інформації в нашій країні - це відведення інформації маніпулятивної ролі, яка була панівною за роки незалежності України, і яка не може розглядатися в аксіологічному сенсі.

Поступові трансформації, які відбуваються шляхом революційних змін в українському суспільстві показують, що українське суспільство стало на шлях розриву з цим гіпертрофованим зв'язком залежності населення від влади і слабким зворотнім зв'язком, про який писав Г. Почепцов [12; 38]. Тому до українців поступово приходить розуміння справжньої сутності владно-інформаційних та відповідно ціннісних відносин. Приходить поступове розуміння того, що не суспільство існує для влади, а влада - для суспільства. 3 цього випливає інша закономірність існування інформації для суспільства. Тому можна стверджувати, що інформація в контексті аксіології для українського соціуму лише починає поставати у важливому та актуальному звучанні як в сфері гуманітарної, так і в сфері технічної науки.

Отже, на підставах вищезазначеного ми можемо зробити частковий висновок - для інформаційної комунікації в Україні притаманна публі- 
цистична журналістика, якій відведена роль інституту просвітництва, що спроможний зробити внесок у розвиток соціальних і духовних інститутів України.

\section{7. Висновки}

На підставах попереднього аналізу ми можемо зробити деякі висновки:

- В якості засобу соціотворення інформацію слід розглядати як соціальний капітал, який формує соціальні зв'язки між різними соціальними групами та збагачує суспільство. В історичному часі людиновимірний характер інформації матеріалізувався у формуванні і поширенні культурно-гуманітарного, освітньо-наукового, економічного і політичного простору. Зазнавши країнознавчих реакцій ці простори відобразили як приклади взаємозбагачення, так і факти відвертої нетерпимості і боротьби.

- Поширення меж і можливостей інформаційного середовища існування людини породило феномен соціальних мереж як місця спрямованого на створення якісно нових форм соціальних відносин $\mathrm{i}$ суспільного буття. Соціальні мережі стали місцем об'єктивізації феномену масової креативної творчості, результатом якої стає народження нових або зміцнення існуючих цінностей та ідеалів.

- Спонуканню окремих соціальних груп суспільства до соціотворчості сприяють такі властивості інформації, як 1) повнота; 2) достовірність; 3) доступність; 4) складність; 5) важливість; 6) актуальність; 7) зрозумілість. Саме вони визначають цінність інформації як загальносоціального надбання і покликанню до і-життя «нового формату історії» як способу спілкування з е-аудиторією та можливості щодо розшифрування соціального коду іншої культури.

- Сьогодні і-простір є не тільки глобальним «будинком», де відбувається постійне спілкування його мешканців між собою, але й $є$ місцем зустрічі людської свободи і технологій маніпуляції свідомістю. Технології «like», «fake», «інформаційний викид» тощо, дозволяють ефективно керувати настроями певних соціальних та етнічних груп та спрямовувати природну людську «боротьбу за визнання» у потрібному напрямі. В умовах розриву з традицією стає неможливим спиратися на традиційні цінності і норми моралі. Електрона культура формує нову соціальну реальність, яка позбавлена свого етнічного, національного та історичного підгрунтя. 
- Особливістю інформаційного простору України є його залежність від публіцистичної журналістики. Редакційна політика і особистісні ціностні уподобання працівників регіональних і національних ЗМІ роблять інформаційний простір Україні надто вразливим з точки зору наповнення його загальнонаціональним аксиологічно орієнтованим продуктом.

На додаток це ще пов'язано з низкою причин:

Перша причина пов'язана 3 феноменом юнівелізації журналістського корпусу, слабкій професійній підготовці та відсутності життєвого досвіду у більшості представників журналістської спільноти.

Друга - з відсутністю національної громадянської площадки щодо обговорення найважливіших проблем державного розвитку, в тому числі й у сфері гуманітарної та інформаційної політики. Такою площадкою могли бути громадське телебачення і радіо, які за низкою причин як незалежні громадські інститути так і не відбулися.

Третя причина пов'язана 3 домінуванням в інформаційному просторі України закордонних 3MI, приватного інтересу та інтересу олігархічного капіталу.

Четверта - з відсутністю чіткої і послідовної державної політики, яка б гарантувала свободу слова і думок та сприяла формуванню терпимості і толерантності між соціальними і етнічними групами.

Активне входження України у добу інформаційного суспільства відбувається на фоні двох взаємопов'язаних процесів: національного самоствердження і входження у світовий інформаційний простір.

Дослідження доводять, що актуалізація інформаційної тематики у вітчизняному науковому просторі сприяе декільком соціально вагомим чинникам - усвідомленню проблеми формування інформаційної культури в умовах зростаючої кількості засобів інформації і подальшого впровадження новітніх інформаційно-комунікативних технологій у сферу навчання.

\section{References:}

1. Andrushchenko V. (2005). Orhanizovane suspilstvo. Problema orhanizatsii ta suspilnoi samoorhanizatsii $v$ period radykalnykh transformatsii $v$ Ukraini na rubezhi stolit: Dosvid sotsialno-filosofskoho analizu [Organized society. The problem of organization and social self-organization during the period of radical transformations in Ukraine at the turn of the century: The experience of socio-philosophical analysis]. Kyiv: TOV „Atlant YuEmSi”. 
2. Huberskyi L. (2004). Informatsiine suspilstvo - stratehiia rozvytku XXI stolittia [Information Society - Strategy for the Development of the XXI Century]. Actual problems of international relations, no. 50, ch. 1, pp. 5-6.

3. Kolodiuk A. (2004). Teoretychne obgruntuvannia poniattia ta vynyknennia informatsiino-ho suspilstva [Theoretical substantiation of the concept and the emergence of informational society]. Borisfen, no. 11, pp. 18-19.

4. Kremen V. (2006). Informatsiino-komunikatsiini tekhnolohii v osviti i formuvannia informatsiinoho suspilstva [Information and communication technologies in education and formation of information society]. Informatics and information technologies in educational institutions, no. 6, pp. 5-9.

5. Kusherets V. (2004). Znannia yak stratehichnyi resurs suspilnykh transformatsii [Knowledge as a strategic resource of social transformations]. Kyiv: Knowledge of Ukraine.

6. Nadolnyi I. (2010). Svitohliad - kliuchova problema derzhavno-upravlinskoi diialnosti [Worldview - a key issue of public-management activities]. Kyiv: NADU.

7. Pryiatelchuk O. (2011). Sotsialno-filosofskyi konstrukt suspilstva ryzyku [The socio-philosophical construct of a society of risk]. Bulletin of the Kiev National University. T. Shevchenko, series "Philosophy, Politics", no. 104, pp. 23-27.

8. Dzoban O. (2015). Informatsiine suspilstvo yak merezhevo-komunikatyvnyi prostir upravlinnia [Information society as a network-communicative management space]. Veche, no. 10 , pp. 7-13.

9. Krysko V. (1999). Sekrety psikhologicheskoy voyny (tseli. zadachi. metody. formy. opyt) [Secrets of the psychological war (goals, tasks, methods, forms, experience)]. Minsk: Kharvest.

10. Mashlykin V. (1999). Evropeyskoe informatsionnoe prostranstvo [European Information Space]. Moscow: Nauka.

11. Melnyk I. (2013). Komunikatyvne seredovyshche v universytetskii osviti [The communicative environment in university education]. Informational education and professional-communicative technologies of the XXI century. Odesa, no. 4 , pp. 226-230.

12.Pocheptsov H. (2004). Propahanda y kontrpropahanda [Propaganda and counter-propaganda]. Moscow: Center.

13. Aksonova V. (2013). Mizhkulturna komunikatsiia yak faktor formuvannia hlobalnoho informatsiino-komunikatyvnoho prostoru [Intercultural communication as a factor in the formation of the global information and communicative space]. Humanitarian Bulletin ZGIA, no. 54, pp. 190-202.

14.Kuznetsov M. (2011). Opyt kommunikatsii v informatsionnuyu epokhu. Issledovatelskiye strategii T.V. Adorno i M. Maklyuena [Experience of communication in the information age. Research Strategies T.V. Adorno and M. Maklueen]. Moscow: YFRAN.

15. Sanakuiev M. (2012). Informatsiia yak systemoorhanizuiuchyi faktor prohresu [Information as a system-organizing factor of progress]. Culture of the peoples of the Black Sea region, no. 242, pp. 172-176.

16. Burde P. (1993). Sotsiologiya politiki [Political Sociology]. Moscow: SocioLogos. 
17. Coleman J. (1988). Social capital in the creation of human capital. American Journal of Sociology, vol. 94, pp. 95-120.

18. Putnam R. (1995). Bowling alone: America's declining social capital. The Journal of Democracy, vol. 6, no. 1, pp. 65-78.

19. Putnam R. (2000). Bowling alone: The collapse and revival of American community. N. Y.: Simon \& Schuster.

20. Macerinskiene I. (2003). Social capital and its impact on economic development // Perspectives of economics of Kaliningrad region and EU development: International scientific conference. Collected articles. Kaliningrad: Mishutkina I.V., pp. 61-68.

21.Florida R. (2007). Kreativnyy klass: lyudi. kotoryye menyayut budushcheye [Creative class: people. which change the future]. Moscow: Klasika-XXI.

22. Beniamin V. (1991). Parizh - stolitsa XIX stoletiya [Paris - the capital of the XIX century]. Moscow: Nauka.

23. Clayton J. (2015). Robert Owen: Pioneer of Social Reforms. London: CHIZINE PUBN.

24. Minyushev F. (2004). Sotsiologiya kultury [Sociology of Culture]. Moscow: Academic Project.

25. Ermakov S. (2018). Sotsialnoye tvorchestvo: $k$ opredeleniyu ponyatiya [Social creativity: to the definition of the concept]. Available at: http://www.intelros.ru/pdf/60_paralel/41/05.pdf (accessed 5 May 2020).

26. Sergeyev K. (2017). «Periferiynoye znaniye» v diskurse kreativnosti: sotsialnyye seti interesnogo ["Peripheral knowledge" in the discourse of creativity: social networks of interesting]. Available at: http://www.metodolog.ru/01375/01375.html (accessed 5 May 2020).

27. Mamardashvili M. (1995). Lektsii o Pruste: (psikhologicheskaya topologiya puti) [Lectures on Proust: (psychological topology of the path)]. Moscow: Ad Margintm.

28.Zhytariuk M. (2008). Sotsiokulturna model zhurnalistyky: tradytsii i novatorstvo: monohrafia [Socio-cultural model of journalism: traditions and innovation: monograph]. Lviv.

29. Demchenko V. (2010). Novitni paradyhmy vyvchennia teorii masovoi komunikatsii v Ukraini (do problemy kontseptualnoi evoliutsii) [New paradigms of the study of the theory of mass communication in Ukraine (to the problem of conceptual evolution)]. State and regions. Series: Social Communications, no. 2, pp. 25-30.

30.Partyko Z. (2008). Obrazna kontseptsiia teorii informatsii: monohrafiia [Outlined concept of information theory: monograph]. Lviv: Afisha.

31.Kvit S. (2008). Masovi komunikatsii [Mass communications]. Kyiv: Kyiv-Mohyla Academy.

32. Buriak V. (2008). Suchasnyi terminolohichnyi dyskurs teorii publitsystyky yak intelektualnyi factor [Modern terminological discourse of the theory of journalism as an intellectual factor]. Visnyk $L N P U$, no. 3, pp. 5-13.

33. Los Y. (2000). Zhurnal «Kultura» (Paryzh) y osoblyvosti formuvannia hromadskoi dumky v Ukraini ta Polshchi (1991-2000) [Magazine "Culture" (Paris) and 
peculiarities of formation of public opinion in Ukraine and Poland (1991-2000)]. Visnyk Lviv University. Journalism series, no. 35-36, pp. 182-194.

34.Potiatynyk B. (2004). Media: kliuchi do rozuminnia [Media: Keys to Understanding]. Lviv: PAIS.

35. Vladymyrov V. (2003). Zhurnalistyka, osoba, suspilstvo: problema rozuminnia: monohrafiia [Journalism, person, society: the problem of understanding: monograph]. Luhansk: Vyd-vo SNU im. V. Dalia.

36. Finkler Yu. (2009). Mas-media ta vlada: tekhnolohiia vzaiemyn: monohrafiia [Mass media and power: technology of relationships: monograph]. Lviv: Az-Art.

37. Kopanieva Ye. (2011). Kohnityvno oriientovani resursy y naukovi Internetkomunikatsii [Cognitive-oriented resources and scientific Internet communications]. Library Bulletin: Scientific-Theoretical and Practical Journal, no. 5, pp. 10-13.

38. Pocheptsov H. (1996). Teoriia komunikatsii [The theory of communication]. Kyiv: "Vakler".

39. Korolko V. (2001). Pablyk rileishnz. Naukovi osnovy, metodyka, praktyka pidruch. [Public relations. Scientific fundamentals, methodology, practice: textbook]. Kyiv: Skarby. 